\title{
Comparison of training and detraining on redox state of rats: gender specific differences
}

\author{
Jovana Bradic ${ }^{1}$, Radica Dragojlovic Ruzicic ${ }^{2}$, Jovana Jeremic ${ }^{1}$, Anica Petkovic ${ }^{1}$, Isidora Stojic ${ }^{1}$, \\ Tamara Nikolic ${ }^{1}$, Vladimir Zivkovic ${ }^{3}$, Ivan Srejovic ${ }^{3}$, Dragan Radovanovic ${ }^{4}$ and Vladimir Lj. \\ Jakovljevic ${ }^{3,5}$
}

${ }^{1}$ University of Kragujevac, Faculty of Medical Sciences, Department of Pharmacy, Kragujevac, Serbia

${ }^{2}$ Belgrade, Serbia, High Medical College of professional Studies "Milutin Milankovic", Belgrade, Serbia

${ }^{3}$ University of Kragujevac, Faculty of Medical Sciences, Department of Physiology, Kragujevac, Serbia

${ }^{4}$ University of Nis, Faculty of Sport and Physical Education, Department of Physiology, Nis, Serbia

${ }^{5}$ University IM Sechenov, $1^{\text {st }}$ Moscow State Medical, Department of Human Pathology, Moscow, Russian Federation

\begin{abstract}
Given the fact that oxidative stress response induced by training/detraining has still not been clarified and may be influenced by gender, the aim of our investigation was to compare the effects of swimming training and detraining on oxidative and antioxidative parameters in rats, with a special focus on sex differences. Wistar albino rats $(n=64)$ were divided into 4 groups: control, trained group, groups exposed to 2 and 4 weeks of detraining. Each group included two subgroups: males and females. After sacrificing, hearts were isolated and retrogradely perfused according to Langendorff technique. Levels of superoxide anion radical, hydrogen peroxide, nitrites and thiobarbituric acid reactive substances were measured in plasma and coronary venous effluent, while reduced glutathione, activities of superoxide dismutase and catalase were measured in erythrocytes. Our results indicate that swimming training doesn't promote oxidative damage, nor act protectively within the heart. However, 2 and 4 weeks of detraining led to a partial lost in exercise-induced adaptation. It seems that moderate-intensity physical exercise of sufficient duration leads to beneficial adaptations, which may be partially lost during detraining period. Positive antioxidative effects of training remained longer in males. Findings of present study may help in elucidation of training and detraining effects on modulation of redox homeostasis, especially from aspect of gender differences.
\end{abstract}

\section{Introduction}

Under normal physiological conditions, pro-oxidants are continuously produced as a result of essential metabolic processes and environmental factors (Pham-Huy et al. 2008). Aerobic organisms possess antioxidant system which consists of variety of enzymatic and nonenzymatic antioxidants that serve to counterbalance the effects of oxidants (Birben et al. 2012). Oxidative stress occurs when there is an imbalance between oxidants and antioxidants in favour of oxidants. Since pro-oxidants are very reactive molecules, they can cause tissue damage interacting in a destructive manner

Correspondence to: Vladimir Lj. Jakovljevic, Department of Physiology, Faculty of Medical Sciences, University of Kragujevac, Svetozara Markovica 69, 34000 Kragujevac, Serbia

E-mail: drvladakgbg@yahoo.com with practically every cellular component (Birben et al. 2012; Rahal et al. 2014).

Regular physical exercise has been shown to exert a myriad of beneficial effects for health, such as promotion of health and lifespan, improvement of quality of life and decrease the incidence of a life-style related diseases (Macera et al. 2003; Vina et al. 2012). Groundbreaking research which gave the first data about the association between exercise and oxidative stress was conducted by Dillardi et al. (1978) approximately 4 decades ago. This finding stimulated further curiosity of many authors regarding the role of reactive oxygen species (ROS) and reactive nitrogen species (RNS) in skeletal muscle and other metabolically active organ during physical exercise (Davies et al. 1982; Ammeren et al. 1992; Gomez-Cabrera et al. 2008). Numerous papers have been published proving that low physiological levels of pro-oxidants produced in the muscles have an important role in maintenance its normal tone and 
contractility. On the contrary, excessive production of ROS leads to a contractile dysfunction which is followed by muscle weakness and fatigue (Powers and Jackson 2008; Rahal et al. 2014). It has been established that swimming training causes changes in antioxidant enzymes, alters muscle gene expression, thus contributing to exercise-induced adaptations to skeletal muscle (Venditti and Di Meo 1997; Elikov 2016; Ruzicic et al. 2016). However it should be taken into consideration that various factors influence the oxidative stress response to swimming training, such as type of exercise, intensity, duration, gender and age of athletes etc. (Ruzicic et al. 2016).

Interestingly, prolonged cessation of training stimulus, known as detraining, may abolish training-induced adaptations in response to oxidative stress and antioxidant status markers (Fatouros et al. 2004; Agarwal et al. 2012). Nevertheless there is a lack of data referring to the oxidative stress response to detraining.

Gender differences in response to exercise-induced oxidative stress have gained increased attention despite controversial results (Liu et al. 2000; Balci and Pepe 2012; Farhat et al. 2017). To our best knowledge there are just a few studies which explored the potential gender difference in oxidative stress markers and antioxidant defense system in the period of detraining.

Given the fact that oxidative stress response induced by detraining has still not been clarified and may be influenced by gender, the aim of our investigation was to compare the effects of swimming training and detraining on oxidative stress parameters and parameters of antioxidant defense system in rats, with a special focus on sex differences.

\section{Materials and Methods}

The study was performed in the laboratory for cardiovascular physiology of the Faculty of Medical Sciences, University of Kragujevac, Serbia. It was approved and performed in accordance with the regulatives of the Faculty's Ethical committee for the welfare of laboratory animals and principles of the Good laboratory practice and European Council Directive (86/609/EEC).

\section{Subjects}

Sixty four Wistar albino rats (males and females, eight weeks old at the beginning of the experiment, body weight 200 $\pm 50 \mathrm{~g}$ ) were included in the study. The animals were housed at temperature of $22 \pm 1^{\circ} \mathrm{C}$, with 12 hours of automatic illumination daily. They consumed commercial rat food $(20 \%$ protein rat food, Veterinary institute Subotica, Serbia) and water ad libitum.

\section{Exercise training protocol}

Rats were divided into 4 groups, while each group consisted of 2 subgroups, males (M) and females (F). The first group was control group (C), subgroups CM and CF $(n=8$ for each subgroup). The second group was trained group (T), subgroups TM and TF ( $n=8$ for each subgroup). The third group included 2 weeks detrained animals (D2), i.e., animals who were subjected to training, followed by 2 weeks of detraining period, subgroups DM2 and DF2 $(n=8$ for each subgroups). The forth group consisted of 4 weeks detrained animals (D4), i.e., animals who were subjected to training followed by 4 weeks of detraining, subgroups DM4 and DF4 ( $n=8$ for each subgroup). Rats from the control group were placed in the pool 5 times a week for 3 minutes to achieve water induced-stress (Lima et al. 2013; Stojanovic Tosic et al. 2015). Trained group included rats who were subjected to moderate intensity exercise, such as swimming training ( 8 weeks, 5 days/week, $60 \mathrm{~min} /$ day) in a specially designed pool according to the protocol in

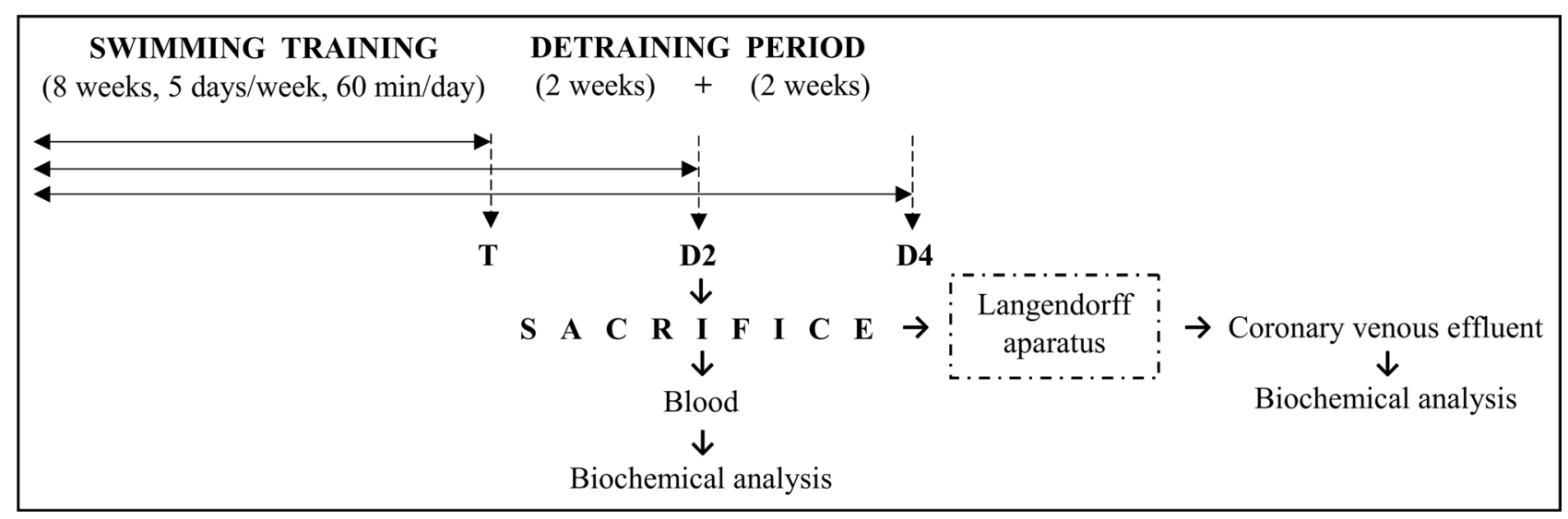

Figure 1. Experimental protocol 
Figure 1A. Week before the experiment, rats were gradually exposed to swimming training from 5 to 15 minutes, in order to familiarize them to the swimming exercise. Subsequently they started with 8 weeks training process. Rats were sacrificed a day after accomplishing training process. On the same day, rats (the same age as in T group) from C groups were sacrificed as well. Animals from DM2, DF2 and DM4, DF4 groups were sacrificed after 2 and 4 weeks of cessation, respectively (Figure 1).

\section{Isolated rat heart preparation}

After a short-term ketamine/xylazine-induced narcosis rats were sacrificed by decapitation. The chest was then opened via midline thoracotomy. The hearts were immediately removed and immersed in cold saline and were then mounted on a stainless steel cannula of the Langendorff perfusion apparatus to provide retrograde perfusion under gradually increasing coronary perfusion pressure (CPP from 40 to $120 \mathrm{cmH}_{2} \mathrm{O}$ ). Krebs-Henseleit buffer was used for retrograde perfusion (in mmol/l: $\mathrm{NaCl} 118, \mathrm{KCl}$ 4.7, $\mathrm{CaCl}_{2} \times 2 \mathrm{H}_{2} \mathrm{O} 2.5, \mathrm{MgSO}_{4} \times 7 \mathrm{H}_{2} \mathrm{O} 1.7, \mathrm{NaHCO}_{3} 25$, $\mathrm{KH}_{2} \mathrm{PO}_{4} 1.2$, glucose 11 , and pyruvate 2 ). The buffer was balanced with $95 \% \mathrm{O}_{2}$ and $5 \% \mathrm{CO}_{2}$, with a $\mathrm{pH}$ of 7.4 and a temperature of $37^{\circ} \mathrm{C}$. Following the establishment of heart perfusion, the preparations were stabilized within $30 \mathrm{~min}$ with a basal coronary perfusion pressure of $70 \mathrm{cmH}_{2} \mathrm{O}$. After the stabilization period, the perfusion pressure was reduced to 50 and $40 \mathrm{cmH}_{2} \mathrm{O}$ and then gradually increased to $60,80,100$ and $120 \mathrm{cmH}_{2} \mathrm{O}$ to establish coronary autoregulation.

\section{Biochemical analysis}

In order to test systemic oxidative stress response to training, after animal sacrifice blood samples for biochemical analysis were collected from jugular vein. After centrifugation of heparinised venous blood, plasma and erythrocytes were separated. In plasma the following parameters of redox balance were determined: the levels of superoxide anion radical $\left(\mathrm{O}_{2}^{-}\right)$, nitrites $\left(\mathrm{NO}_{2}{ }^{-}\right)$, hydrogen peroxide $\left(\mathrm{H}_{2} \mathrm{O}_{2}\right)$ and index of lipid peroxidation (measured as thiobarbituric acid reactive substances-TBARS). Superoxide dismutase (SOD), catalase (CAT) and reduced glutathione (GSH) were determined in erythrocytes samples. During each CPP coronary venous effluent was collected for the purpose of determination of levels of pro-oxidants such as $\mathrm{O}_{2}, \mathrm{NO}_{2}{ }^{-}, \mathrm{H}_{2} \mathrm{O}_{2}$ and TBARS. Analyses of the pro-oxidants were performed using the same methods as when analyzing plasma samples and coronary venous effluent except $\mathrm{NO}_{2}{ }^{-}$where the protocol differs. Biochemical parameters were measured spectrophotometrically, using UV-1800 Shimadzu UV spectrophotometer, Japan.

\section{Superoxide anion radical determination $\left(\mathrm{O}_{2}^{-}\right)$}

The level of superoxide anion radical $\left(\mathrm{O}_{2}{ }^{-}\right)$was measured using nitro blue tetrazolium (NBT) reaction in TRIS-buffer combined with plasma sample or coronary venous effluent. The measurement was performed at a wavelength of $530 \mathrm{~nm}$. For $\mathrm{O}_{2}{ }^{-}$determination in coronary venous effluent the Krebs-Henseleit solvent was used as the blank control, while in case of plasma samples distilled water served as a blank control (Auclair and Voisin 1985).

\section{Hydrogen peroxide determination $\left(\mathrm{H}_{2} \mathrm{O}_{2}\right)$}

The protocol for measurement of hydrogen peroxide $\left(\mathrm{H}_{2} \mathrm{O}_{2}\right)$ is based on oxidation of phenol red in the presence of horseradish peroxidase. $200 \mu \mathrm{l}$ sample with $800 \mu \mathrm{l}$ PRS (phenol red solution) and $10 \mu \mathrm{POD}$ (horseradish peroxidase) were combined (1:20). The level of $\mathrm{H}_{2} \mathrm{O}_{2}$ was measured at $610 \mathrm{~nm}$. For $\mathrm{H}_{2} \mathrm{O}_{2}$ determination in coronary venous effluent the Krebs-Henseleit solvent was used as the blank control, while in case of plasma samples distilled water served as a blank control (Pick and Keisari 1980).

\section{Nitrite determination $\left(\mathrm{NO}_{2}^{-}\right)$}

Nitric oxide (NO) decomposes rapidly to form stable metabolite nitrite/nitrate products. Nitrite $\left(\mathrm{NO}_{2}{ }^{-}\right)$was determined as an index of nitric oxide production with Griess reagent. For $\mathrm{NO}_{2}{ }^{-}$determination in plasma $0.1 \mathrm{ml}$ $3 \mathrm{~N}$ PCA (perchloride acid), $0.4 \mathrm{ml} 20 \mathrm{mM}$ ethylenediaminetetraacetic acid (EDTA), and $0.2 \mathrm{ml}$ plasma were put on ice for $15 \mathrm{~min}$, then centrifuged $15 \mathrm{~min}$ at 6,000 rpm. After pouring off the supernatant, $220 \mu \mathrm{K}_{2} \mathrm{CO}_{3}$ was added. Nitrites were measured at $550 \mathrm{~nm}$. Distilled water was used as a blank probe.

For $\mathrm{NO}_{2}^{-}$determination in coronary venous effluent, $0.5 \mathrm{ml}$ of the perfusate was precipitated with $200 \mu \mathrm{l}$ of $30 \%$ sulfosalicylic acid, mixed for $30 \mathrm{~min}$ and centrifuged at $3000 \times g$. Equal volumes of the supernatant and Griess reagent were mixed and stabilized for $10 \mathrm{~min}$ in the dark, and then the sample was measured spectrophotometrically at a wavelength of $543 \mathrm{~nm}$. The nitrite concentrations were determined using sodium nitrite as the standard (Green et al. 1982).

\section{Determination of the index of lipid peroxidation measured as TBARS}

The degree of lipid peroxidation in the sample (plasma and coronary venous effluent) was estimated by measuring of TBARS using 1\% TBA (thiobarbituric acid) in $0.05 \mathrm{NaOH}$, incubated with sample at $100^{\circ} \mathrm{C}$ for $15 \mathrm{~min}$ and read at $530 \mathrm{~nm}$. TBA extract was obtained by combining $0.8 \mathrm{ml}$ 
sample and $0.4 \mathrm{ml}$ trichloro acetic acid (TCA), then samples were put on ice for $10 \mathrm{~min}$, and centrifuged for $15 \mathrm{~min}$ at $6,000 \mathrm{rpm}$. The Krebs-Henseleit solvent was used as a blank control when TBARS was determined in coronary venous effluent, while in case of plasma sample distilled water was used (Ohkawa et al. 1979).

\section{Determination of antioxidant enzymes (CAT, SOD)}

Isolated RBCs were washed three times with three volumes of ice-cold $0.9 \mathrm{mmol} / \mathrm{l} \mathrm{NaCl}$ and hemolysates containing about $50 \mathrm{~g} \mathrm{Hb} / 1$ (prepared according to McCord and Fridovich 1969) were used for the determination of CAT activity (Beutler 1982). Then $50 \mu$ l CAT buffer, $100 \mu \mathrm{l}$ sample, and $1 \mathrm{ml} 10 \mathrm{mM} \mathrm{H}_{2} \mathrm{O}_{2}$ were added to the samples. Detection was performed at $360 \mathrm{~nm}$. SOD activity was determined by the epinephrine method (Misra and Fridovich 1972). A $100 \mu \mathrm{l}$ lysate and $1 \mathrm{ml}$ carbonate buffer were mixed, and then $100 \mu \mathrm{l}$ of epinephrine was added. Detection was performed at $470 \mathrm{~nm}$. Distilled water was used as a blank probe.

\section{Determination of reduced glutathione (GSH)}

Level of GSH was determined spectrophotometrically, and it is based on GSH oxidation via 5,5-dithiobis-6,2-nitrobenzoic acid. GSH extract was obtained by combining $0.1 \mathrm{ml} 0.1 \%$ EDTA, $400 \mu \mathrm{l}$ haemolysate, and $750 \mu \mathrm{l}$ precipitation solution (containing $1.67 \mathrm{~g}$ metaphosphoric acid, $0.2 \mathrm{~g}$ EDTA, $30 \mathrm{~g} \mathrm{NaCl}$, and filled with distilled water until $100 \mathrm{ml}$; the solution is stable for 3 weeks at $\left.+4^{\circ} \mathrm{C}\right)$. After mixing in the vortex machine and extraction on cold ice (15 $\mathrm{min})$, it was centrifuged on $4000 \mathrm{rpm}$ (10 min). Distilled water was used as a blank probe. Measuring was performed at $420 \mathrm{~nm}$. The concentration is expressed as nanomoles per milliliter of RBCs (Beutler 1975).

\section{Statistical analysis}

IBM SPSS Statistics 20.0 for Windows was used for statistical analysis. Values were expressed as mean \pm standard deviation (SD). Descriptive statistics were used to calculate arithmetic mean with dispersion measures (standard deviation SD and standard error SE). Distribution of data was checked by Shapiro-Wilk test. Where distribution between groups was normal, statistical comparisons were performed using the one-way ANOVA tests with a Tukey's post hoc test for multiple comparisons. Kruskal-Wallis was used for comparison between groups where the distribution of data was different than normal. Values of $p<$ 0.05 were considered to be statistically significant, while values of $p<0.01$ were considered to be statistically high significant.

\section{Results}

\section{Cardiac oxidative stress markers}

\section{Levels of superoxide anion radical $\left(\mathrm{O}_{2}^{-}\right)$}

There was a statistically significant difference between groups in the level of $\mathrm{O}_{2}{ }^{-}$as determined by one-way ANOVA $\left(\mathrm{F}(7,121)=7,362, p=0.00\right.$ for $\mathrm{CPP} 40 \mathrm{cmH}_{2} \mathrm{O}, \mathrm{F}(7,121)=$ $3,155, p=0.01$ for CPP $60 \mathrm{cmH}_{2} \mathrm{O}, \mathrm{F}(7,121)=9.229, p=$ 0.00 for CPP $80 \mathrm{cmH}_{2} \mathrm{O}, \mathrm{F}(7,121)=9,769, p=0.00$ for CPP $100 \mathrm{cmH}_{2} \mathrm{O}, \mathrm{F}(7,121)=11,322, p=0.00$ for $\left.\mathrm{CPP} 120 \mathrm{cmH}_{2} \mathrm{O}\right)$. A Tukey post hoc test revealed significant decrease in the level of $\mathrm{O}_{2}{ }^{-}$in trained females compared to their controls at all CPP $\left(\mathrm{p}=0.009\right.$ at $\mathrm{CPP} 40 \mathrm{cmH}_{2} \mathrm{O}, p=0.015$ at $\mathrm{CPP} 60 \mathrm{cmH}_{2} \mathrm{O}$, $p=0.018$ at $\mathrm{CPP} 80 \mathrm{cmH}_{2} \mathrm{O}, p=0.006$ at $\mathrm{CPP} 100 \mathrm{cmH}_{2} \mathrm{O}$, $p=0.002$ at $\mathrm{CPP} 120 \mathrm{cmH}_{2} \mathrm{O}$ ). The same trend was revealed in trained males compared to their controls at all CPP values ( $\mathrm{p}=0.004$ at $\mathrm{CPP} 40 \mathrm{cmH}_{2} \mathrm{O}, p=0.008$ at $\mathrm{CPP} 60 \mathrm{cmH}_{2} \mathrm{O}$, $p=0.005$ at $\mathrm{CPP} 80 \mathrm{cmH}_{2} \mathrm{O}, p=0.003$ at $\mathrm{CPP} 100 \mathrm{cmH}_{2} \mathrm{O}$, $p=0.002$ at $\mathrm{CPP} 120 \mathrm{cmH}_{2} \mathrm{O}$ (Figure 2A). This parameter was significantly higher in 4 weeks detrained females than in 2 weeks detrained females at CPP $80-120 \mathrm{cmH}_{2} \mathrm{O}(\mathrm{p}=0.039$ at $\mathrm{CPP} 80 \mathrm{cmH}_{2} \mathrm{O}, p=0.032$ at $\mathrm{CPP} 100 \mathrm{cmH}_{2} \mathrm{O}, p=0.029$ at $\mathrm{CPP} 120 \mathrm{cmH}_{2} \mathrm{O}$ ). On the other hand, level of $\mathrm{O}_{2}{ }^{-}$in 4 weeks detrained males was lower than in 2 weeks detrained males at CPP $40-80 \mathrm{cmH}_{2} \mathrm{O}\left(\mathrm{p}=0.029\right.$ at $\mathrm{CPP} 40 \mathrm{cmH}_{2} \mathrm{O}$, $p=0.021$ at CPP $60 \mathrm{cmH}_{2} \mathrm{O}, p=0.034$ at $\mathrm{CPP} 80 \mathrm{cmH}_{2} \mathrm{O}$ ). Significantly lower level of $\mathrm{O}_{2}^{-}$was revealed in 4 weeks detrained males compared to 4 weeks detrained females at all CPP values $\left(p=0.031\right.$ at $\mathrm{CPP} 40 \mathrm{cmH}_{2} \mathrm{O}, p=0.007$ at $\mathrm{CPP}$ $60 \mathrm{cmH}_{2} \mathrm{O}, p=0.002$ at $\mathrm{CPP} 80 \mathrm{cmH}_{2} \mathrm{O}, p=0.004$ at CPP $100 \mathrm{cmH}_{2} \mathrm{O}, p=0.006$ at $\mathrm{CPP} 120 \mathrm{cmH}_{2} \mathrm{O}$ ) (Figure 2B). There was a decrease in the level of this parameter in trained females compared to 2 weeks detrained females at all CPP $(p=0.023$ at CPP 40, $p=0.005$ at CPP 60, $p=0.007$ at CPP $80 \mathrm{cmH}_{2} \mathrm{O}$, $p=0.014$ at $\mathrm{CPP} 100 \mathrm{cmH}_{2} \mathrm{O}, p=0.034$ at $\mathrm{CPP} 120 \mathrm{cmH}_{2} \mathrm{O}$ ) and 4 weeks detrained females at all CPP $(p=0.020$ at CPP $40 \mathrm{cmH}_{2} \mathrm{O}, p=0.006$ at CPP $60 \mathrm{cmH}_{2} \mathrm{O}, p=0.002$ at CPP $80 \mathrm{cmH}_{2} \mathrm{O}, p=0.003$ at $\mathrm{CPP} 100 \mathrm{cmH}_{2} \mathrm{O}, p=0.015$ at $\mathrm{CPP}$ $120 \mathrm{cmH}_{2} \mathrm{O}$ ) (Figure 2C). Training led to a decrease in the level of $\mathrm{O}_{2}^{-}$in males compared to 2 weeks detrained males at all CPP values $\left(p=0.015\right.$ at CPP $40 \mathrm{cmH}_{2} \mathrm{O}, p=0.011$ at CPP $60 \mathrm{cmH}_{2} \mathrm{O}, p=0.017$ at CPP $80 \mathrm{cmH}_{2} \mathrm{O}, p=0.019$ at CPP $100 \mathrm{cmH}_{2} \mathrm{O}, p=0.015$ at CPP $120 \mathrm{cmH}_{2} \mathrm{O}$ ). In 4 weeks detrained males values were higher than in trained males at 100 and $120 \mathrm{cmH}_{2} \mathrm{O}\left(p=0.036\right.$ at $\mathrm{CPP} 100 \mathrm{cmH}_{2} \mathrm{O}, p=0.033$ at CPP $120 \mathrm{cmH}_{2} \mathrm{O}$ ) (Figure 2D).

\section{Levels of nitrites $\left(\mathrm{NO}_{2}^{-}\right)$}

One-way ANOVA revealed there was a significant difference between groups in the level of $\mathrm{O}_{2}{ }^{-}(\mathrm{F}(7,121)=2,112, p=0.03$ 
for $\mathrm{CPP}=40 \mathrm{cmH}_{2} \mathrm{O}, \mathrm{F}(7,121)=2,267, p=0.02$ for $\mathrm{CPP}=$ $60 \mathrm{cmH}_{2} \mathrm{O}, \mathrm{F}(7,121)=3,569, p=0.00$ for $\mathrm{CPP}=80 \mathrm{cmH}_{2} \mathrm{O}$, $\mathrm{F}(7,121)=7,562, p=0.00$ for $\mathrm{CPP}=100 \mathrm{cmH}_{2} \mathrm{O}, \mathrm{F}(7,121)=$ $6,7822, p=0.00$ for $\mathrm{CPP}=120 \mathrm{cmH}_{2} \mathrm{O}$ ). There was a decrease in the level of this parameter in trained females compared to control females at 100 and $120 \mathrm{cmH}_{2} \mathrm{O}(p=0.023$ at CPP $100 \mathrm{cmH}_{2} \mathrm{O}, p=0.021$ at $\mathrm{CPP} 120 \mathrm{cmH}_{2} \mathrm{O}$ ) (Figure 3A). In addition level of $\mathrm{NO}_{2}^{-}$observed in trained females in comparison to $2(p=0.032)$ and 4 weeks detrained females were lower at $\mathrm{CPP}=120 \mathrm{cmH}_{2} \mathrm{O}(p=0.039)$ (Figure 3C).

\section{Levels of hydrogen peroxide $\left(\mathrm{H}_{2} \mathrm{O}_{2}\right)$}

A significant difference between groups in the level of $\mathrm{H}_{2} \mathrm{O}_{2}$ was found $(\mathrm{F}(7,121)=2,122, p=0.002$ for $\mathrm{CPP}=$
$40 \mathrm{cmH}_{2} \mathrm{O}, \mathrm{F}(7,121)=2,346, p=0.00$ for $\mathrm{CPP}=60 \mathrm{cmH}_{2} \mathrm{O}$, $\mathrm{F}(7,121)=8,791, p=0.00$ for $\mathrm{CPP}=80 \mathrm{cmH}_{2} \mathrm{O}, \mathrm{F}(7,121)$ $=7,269, p=0.00$ for $\mathrm{CPP}=100 \mathrm{cmH}_{2} \mathrm{O}, \mathrm{F}(7,121)=10,289$, $p=0.00$ for $\mathrm{CPP}=120 \mathrm{cmH}_{2} \mathrm{O}$ ). After the training, level of $\mathrm{H}_{2} \mathrm{O}_{2}$ was significantly decreased compared to the control group at male rats $\left(p=0.030\right.$ at CPP $40 \mathrm{cmH}_{2} \mathrm{O}, p=0.032$ at $\mathrm{CPP} 60 \mathrm{cmH}_{2} \mathrm{O}, p=0.031$ at $\mathrm{CPP} 80 \mathrm{cmH}_{2} \mathrm{O}, p=0.026$ at CPP $100 \mathrm{cmH}_{2} \mathrm{O}, p=0.029$ at CPP $\left.120 \mathrm{cmH}_{2} \mathrm{O}\right)$. The same trend was noticed in female rats $(p=0.043$ at CPP $40 \mathrm{cmH}_{2} \mathrm{O}, p=0.035$ at $\mathrm{CPP} 60 \mathrm{cmH}_{2} \mathrm{O}, p=0.033$ at $\mathrm{CPP}$ $80 \mathrm{cmH}_{2} \mathrm{O}, p=0.029$ at $\mathrm{CPP} 100 \mathrm{cmH}_{2} \mathrm{O}, p=0.026$ at CPP $120 \mathrm{cmH}_{2} \mathrm{O}$ ) (Figure 4A). Gender difference in the level of $\mathrm{H}_{2} \mathrm{O}_{2}$ in 2 weeks detrained females compared to 2 weeks detrained males was observed, where levels were lower in female rats $\left(p=0.028\right.$ at CPP $100 \mathrm{cmH}_{2} \mathrm{O}, p=0.022$ at CPP
A

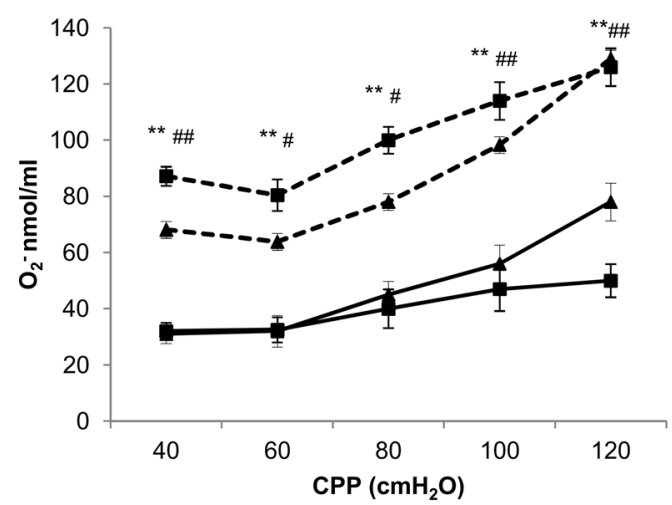

C

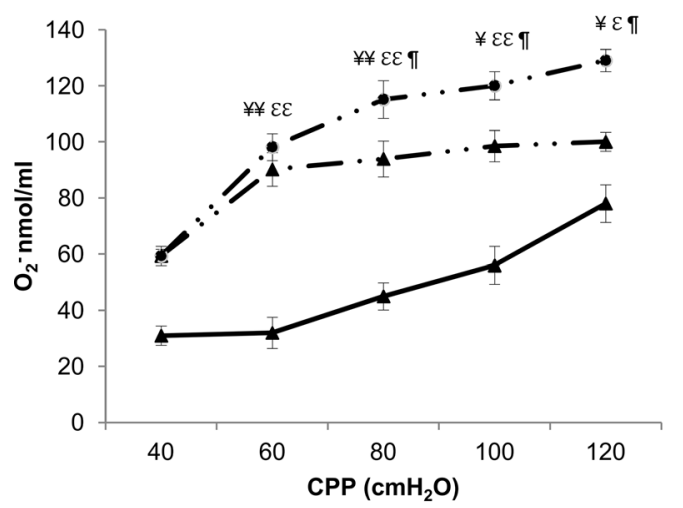

B

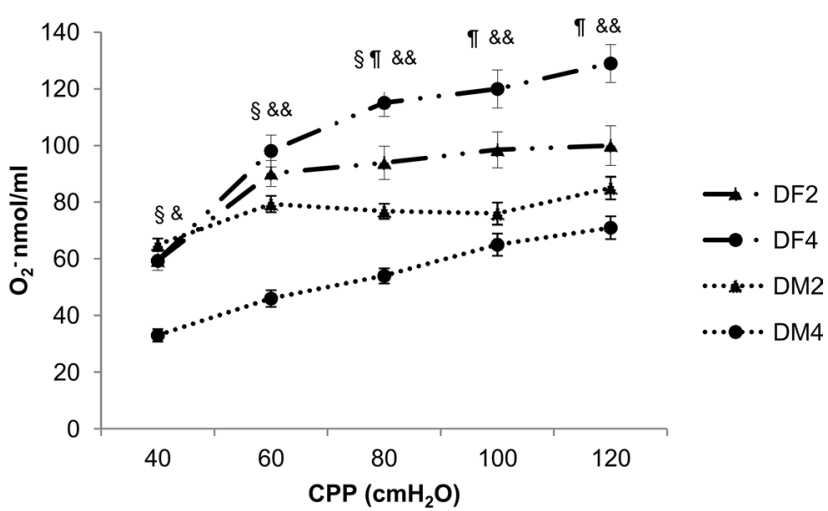

D

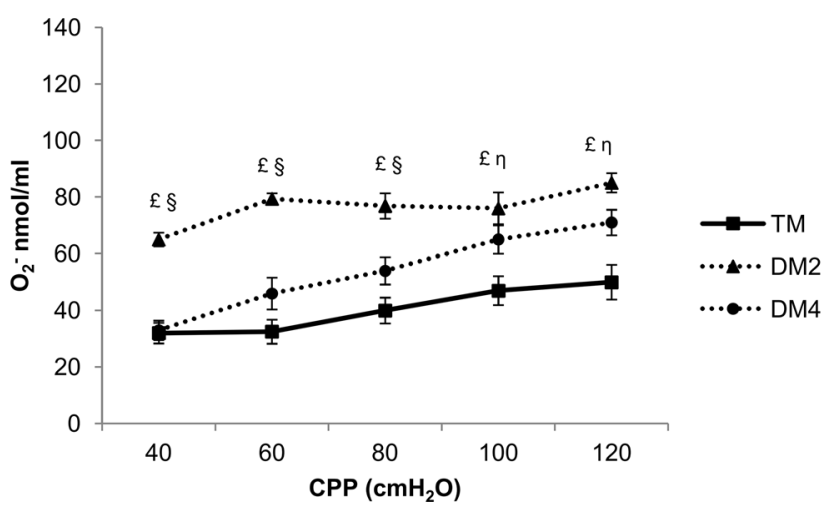

Figure 2. Effects of training/detraining on superoxide anion radical level determined in coronary venous effluent $\left(\mathrm{O}_{2}{ }^{-}\right)$. A. Comparison between control and trained groups. B. Comparison between 2 and 4 weeks detrained groups. C. Comparison between trained, 2 and 4 weeks detrained females. D. Comparison between trained, 2 and 4 weeks detrained males. ${ }^{*} p<0.05,{ }^{* *} p<0.01 \mathrm{TM} v$ s. CM; ${ }^{\#} p<$

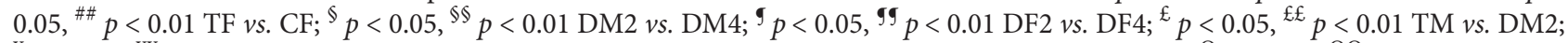

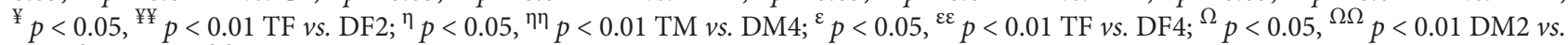
$\mathrm{DF} 2{ }^{\&} p<0.05,{ }^{\& \&} p<0.01 \mathrm{DM} 4$ vs. DF4. Data are means \pm SD. CPP, coronary perfusion pressure; TM, trained males; DM2, 2 weeks detrained males; DM4, 4 weeks detrained males; CM, control males; TF, trained females; DF2, 2 weeks detrained females; DF4, 4 weeks detrained females; $\mathrm{CF}$, control females. 


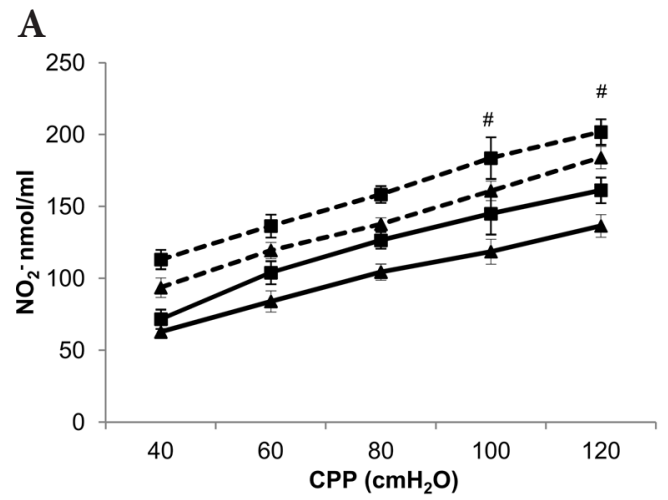

C

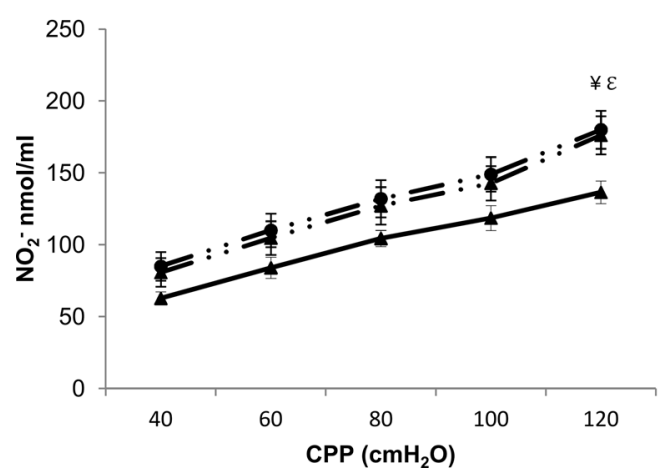

B
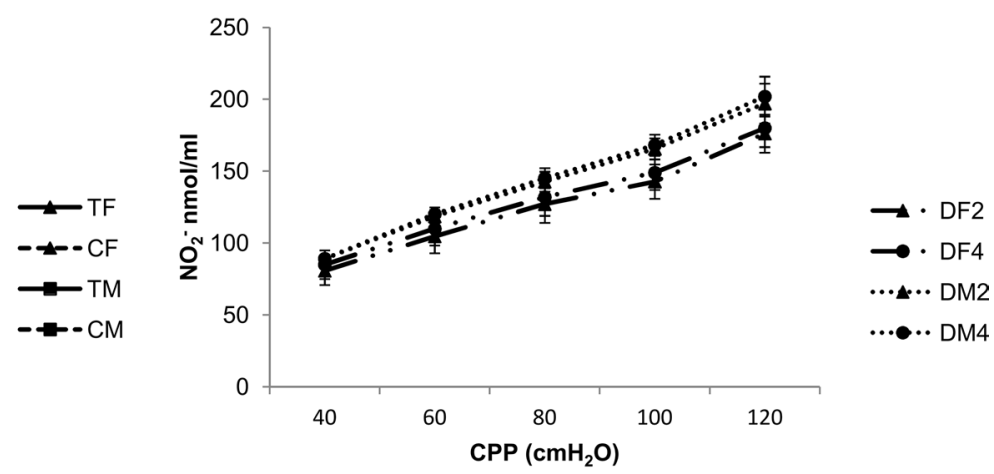

D
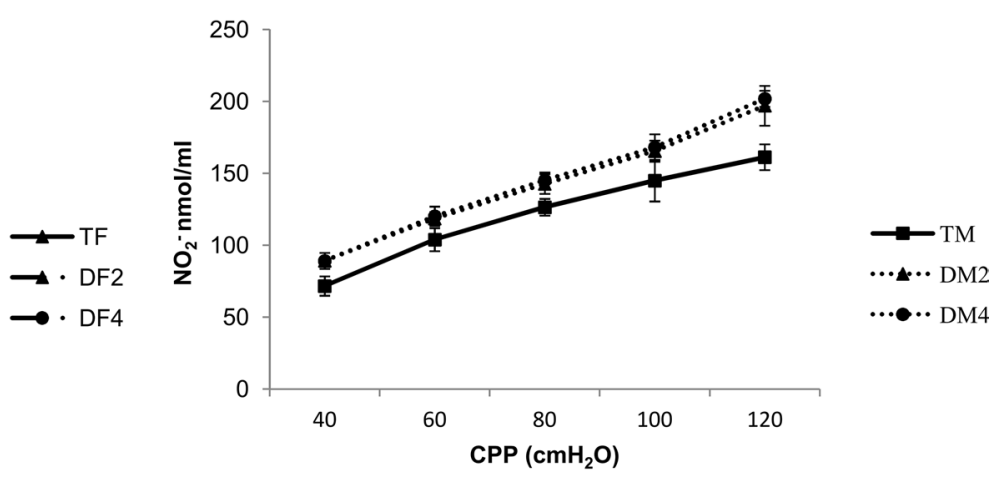

Figure 3. Effects of training/detraining on nitrite level determined in coronary venous effluent $\left(\mathrm{NO}_{2}{ }^{-}\right)$. A. Comparison between control and trained groups. B. Comparison between 2 and 4 weeks detrained groups. C. Comparison between trained, 2 and 4 weeks detrained females. D. Comparison between trained, 2 and 4 weeks detrained males. ${ }^{* *} p<0.05,{ }^{* *} p<0.01 \mathrm{TM} v$ s. CM; ${ }^{\#} p<0.05,{ }^{\# \#} p<0.01 \mathrm{TF}$

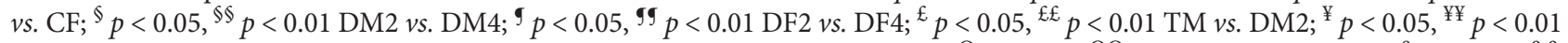
TF vs. DF2; ${ }^{\eta} p<0.05, \eta^{\eta \eta} p<0.01$ TM vs. DM4; ${ }^{\varepsilon} p<0.05,{ }^{\varepsilon \varepsilon} p<0.01$ TF vs. DF4; ${ }^{\Omega} p<0.05,{ }^{\Omega} \Omega<<0.01$ DM2 vs. DF2; ${ }^{\&} p<0.05,{ }^{\& \&}$ $p<0.01$ DM4 vs. DF4. Data are means \pm SD. For abbreviations, see Fig. 2.

$120 \mathrm{cmH}_{2} \mathrm{O}$ ). Furthermore, level of this parameter was lower in 4 weeks detrained females compared to 4 weeks detrained males $\left(p=0.013\right.$ at CPP $100 \mathrm{cmH}_{2} \mathrm{O}, p=0.018$ at $\mathrm{CPP} 120 \mathrm{cmH}_{2} \mathrm{O}$ ) (Figure 4B). In trained females, level of $\mathrm{H}_{2} \mathrm{O}_{2}$ was significantly lower than in 2 weeks detrained at CPP 60-120 $\mathrm{cmH}_{2} \mathrm{O}\left(p=0.046\right.$ at CPP $60 \mathrm{cmH}_{2} \mathrm{O}, p=$ 0.038 at $\mathrm{CPP} 80 \mathrm{cmH}_{2} \mathrm{O}, p=0.029$ at $\mathrm{CPP} 100 \mathrm{cmH}_{2} \mathrm{O}, p=$ 0.035 at CPP $120 \mathrm{cmH}_{2} \mathrm{O}$ ). In 4 weeks detrained females, level of this parameter was higher in comparison to trained females $\left(p=0.045\right.$ at CPP $60 \mathrm{cmH}_{2} \mathrm{O}, p=0.039$ at $\mathrm{CPP}$ $80 \mathrm{cmH}_{2} \mathrm{O}, p=0.037$ at CPP $120 \mathrm{cmH}_{2} \mathrm{O}$ (Figure 4C). The same trend was revealed in males when compared trained group to 2 weeks detrained $\left(p=0.035\right.$ at $\mathrm{CPP} 40 \mathrm{cmH}_{2} \mathrm{O}$, $p=0.031$ at CPP $60 \mathrm{cmH}_{2} \mathrm{O}, p=0.022$ at CPP $80 \mathrm{cmH}_{2} \mathrm{O}$, $p=0.007$ at CPP $100 \mathrm{cmH}_{2} \mathrm{O}, p=0.006$ at CPP $\left.120 \mathrm{cmH}_{2} \mathrm{O}\right)$. There was an increase after 4 weeks of detraining in males compared to training at all CPP values $(p=0.029$ at CPP $40 \mathrm{cmH}_{2} \mathrm{O}, p=0.027$ at $\mathrm{CPP} 60 \mathrm{cmH}_{2} \mathrm{O}, p=0.018$ at $\mathrm{CPP}$ $80 \mathrm{cmH}_{2} \mathrm{O}, p=0.009$ at $\mathrm{CPP} 100 \mathrm{cmH}_{2} \mathrm{O}, p=0.005$ at $\mathrm{CPP}$ $120 \mathrm{cmH}_{2} \mathrm{O}$ ) (Figure 4D).

\section{Levels of TBARS}

There was a significant difference between groups in the level of TBARS $(\mathrm{F}(7,121)=7.229, p=0.00$ for $\mathrm{CPP}=$ $40 \mathrm{cmH}_{2} \mathrm{O}, \mathrm{F}(7,121)=5,671, p=0.00$ for $\mathrm{CPP}=60 \mathrm{cmH}_{2} \mathrm{O}$, $\mathrm{F}(7,121)=3,362, p=0.000$ for $\mathrm{CPP}=80 \mathrm{cmH}_{2} \mathrm{O}, \mathrm{F}(7,121)=$ $2,469, p=0.004$ for $\mathrm{CPP}=100 \mathrm{cmH}_{2} \mathrm{O}, \mathrm{F}(7,121)=10,322$, $p=0.00$ for $\mathrm{CPP}=120 \mathrm{cmH}_{2} \mathrm{O}$. In the trained group, a decrease in level of TBARS was noticed by comparing to the control group in male rats at all CPP $(p=0.019$ at CPP $40 \mathrm{cmH}_{2} \mathrm{O}, p=0.009$ at $\mathrm{CPP} 60 \mathrm{cmH}_{2} \mathrm{O}, p=0.005$ at CPP $80 \mathrm{cmH}_{2} \mathrm{O}, p=0.008$ at $\mathrm{CPP} 100 \mathrm{cmH}_{2} \mathrm{O}, p=0.009$ at $\mathrm{CPP}$ $120 \mathrm{cmH}_{2} \mathrm{O}$ ). Training led to the decrease in the level of this parameter in females at all CPP values compared to controls ( $p=0.013$ at CPP $40 \mathrm{cmH}_{2} \mathrm{O}, p=0.009$ at $\mathrm{CPP} 60 \mathrm{cmH}_{2} \mathrm{O}$, $p=0.007$ at $\mathrm{CPP} 80 \mathrm{cmH}_{2} \mathrm{O}, p=0.006$ at $\mathrm{CPP} 100 \mathrm{cmH}_{2} \mathrm{O}$, $p=0.002$ at $\mathrm{CPP} 120 \mathrm{cmH}_{2} \mathrm{O}$ ) (Figure 5A). There was a significant increase in 2 weeks detrained females compared to 2 weeks detrained males at all CPP values $(p=0.022$ at CPP $40 \mathrm{cmH}_{2} \mathrm{O}, p=0.018$ at $\mathrm{CPP} 60 \mathrm{cmH}_{2} \mathrm{O}, p=0.025$ at $\mathrm{CPP}$ 
A

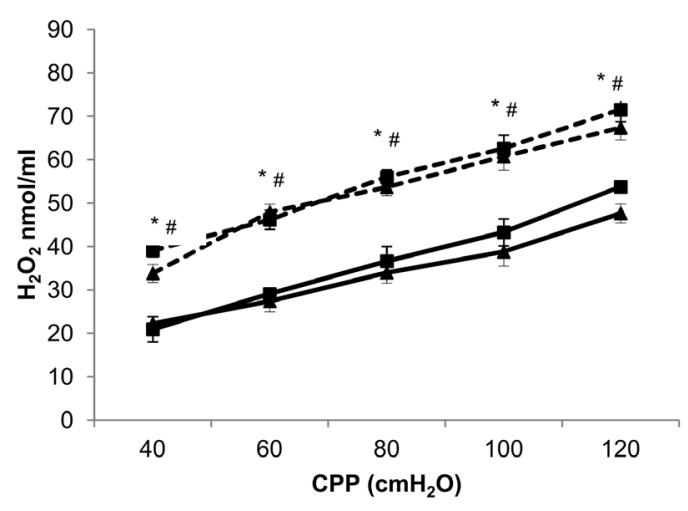

C

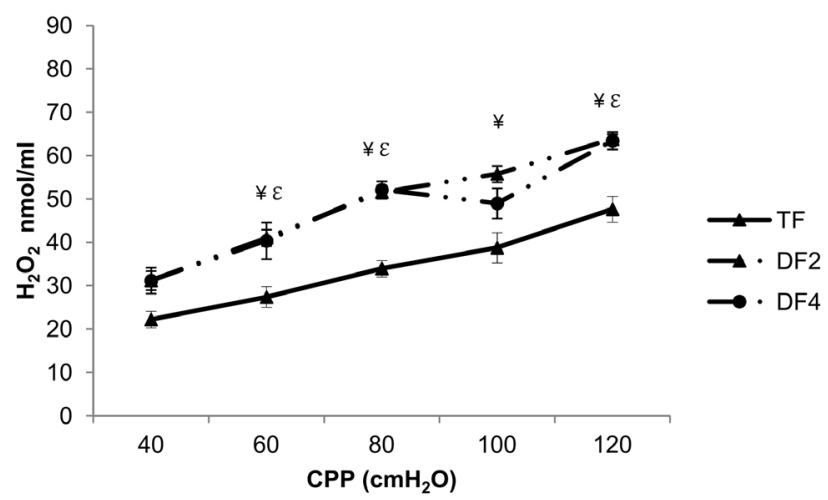

B

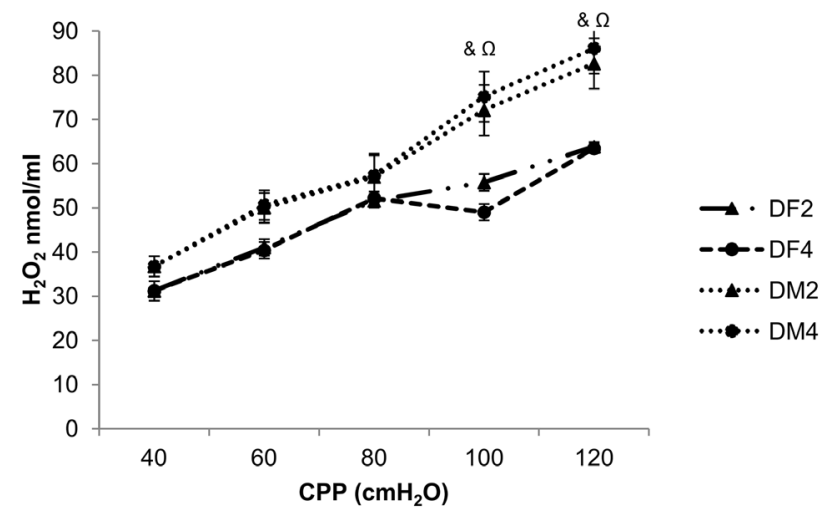

D

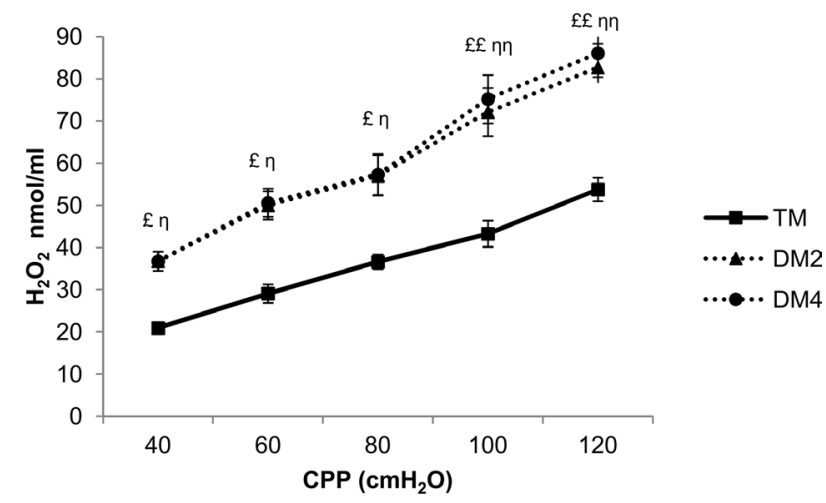

Figure 4. Effects of training/detraining on hydrogen peroxide level determined in coronary venous effluent $\left(\mathrm{H}_{2} \mathrm{O}_{2}\right)$. A. Comparison between control and trained groups. B. Comparison between 2 and 4 weeks detrained groups. C. Comparison between trained, 2 and 4 weeks detrained females. D. Comparison between trained, 2 and 4 weeks detrained males. ${ }^{*} p<0.05,{ }^{* *} p<0.01 \mathrm{TM} v s$. CM; ${ }^{*} p<0.05$,

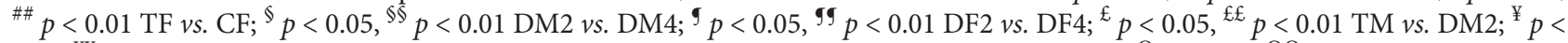

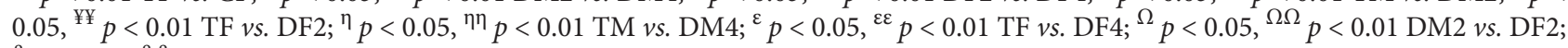
$\& p<0.05,{ }^{\& \&} p<0.01$ DM4 vs. DF4. Data are means \pm SD. For abbreviations, see Fig. 2.

$80 \mathrm{cmH}_{2} \mathrm{O}, p=0.031$ at $\mathrm{CPP} 100 \mathrm{cmH}_{2} \mathrm{O}, p=0.033$ at $\mathrm{CPP}$ $120 \mathrm{cmH}_{2} \mathrm{O}$ ) (Figure 5B). In group of male rats, there was a decrease in values of this parameter in 2 weeks detrained compared to trained rats, but only in the lowest CPP $(p=$ 0.029 at $\mathrm{CPP} 40 \mathrm{cmH}_{2} \mathrm{O}, p=0.032$ at $\mathrm{CPP} 60 \mathrm{cmH}_{2} \mathrm{O}$ ). In 4 weeks detrained males levels were lower than in trained males at the highest $\mathrm{CPP}\left(p=0.022\right.$ at $\mathrm{CPP} 80 \mathrm{cmH}_{2} \mathrm{O}, p=$ 0.027 at CPP $100 \mathrm{cmH}_{2} \mathrm{O}, p=0.029$ at $\mathrm{CPP} 120 \mathrm{cmH}_{2} \mathrm{O}$ ) (Figure 5D).

\section{Systemic redox state}

\section{Levels of superoxide anion radical $\left(\mathrm{O}_{2}^{-}\right)$}

There was a significant difference between groups in the level of $\mathrm{O}_{2}^{-}(\mathrm{F}(7,56)=8.229, p=0.00)$. Significantly lower levels were noticed in trained females compared to 2 weeks detrained females $(p=0.007)$ and trained males in comparison to 2 weeks $(p=0.008)$ and 4 weeks detrained males $(p=0.007)$. There was a decrease in 4 weeks detrained females compared to 2 weeks detrained females $(p=0.009)$. Level of $\mathrm{O}_{2}{ }^{-}$in 4 weeks detrained females was significantly lower than in 4 weeks detrained males ( $p=$ 0,006) (Figure 6A).

\section{Levels of nitrites $\left(\mathrm{NO}_{2}^{-}\right)$}

A significant difference between groups in the level of $\mathrm{NO}_{2}$ was noticed $(\mathrm{F}(7,56)=9,125, p=0.00)$. There was a decrease in the level of $\mathrm{NO}_{2}{ }^{-}$parameter in 2 weeks detrained females in comparison to trained females $(p=0.024)$ and 2 weeks detrained males in comparison to trained males $(p=$ 0.029). Level of this parameter in 4 weeks detrained males was decreased compared to trained males $(p=0.028)$. In addition, level of $\mathrm{NO}_{2}{ }^{-}$in 4 weeks detrained females was increased compared to 2 weeks detrained females $(p=$ 
A

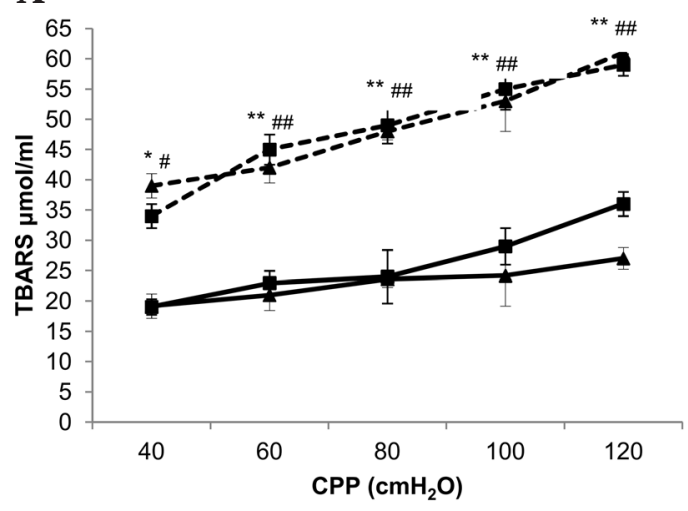

C

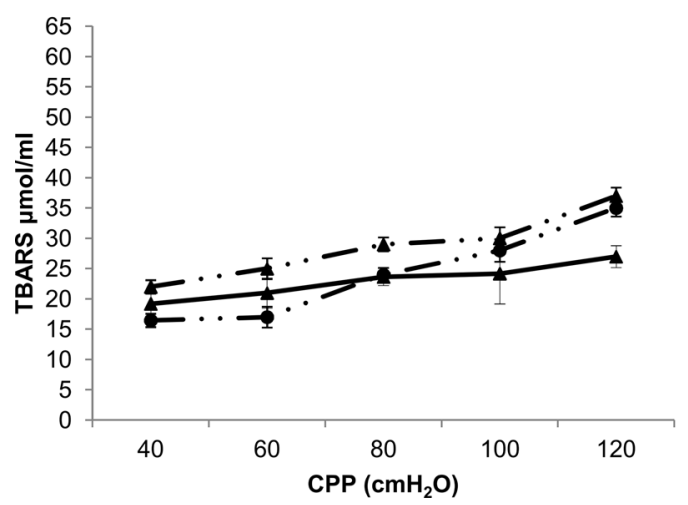

B
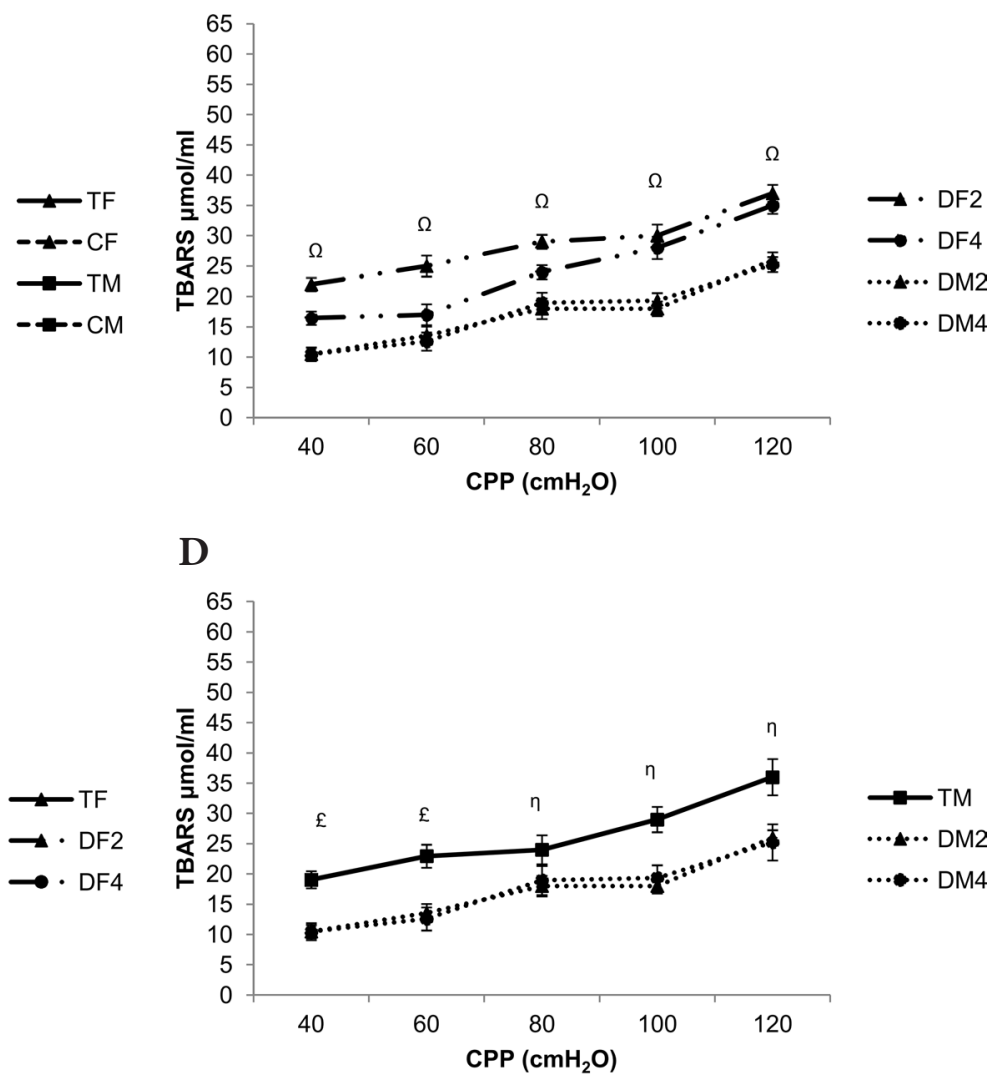

D

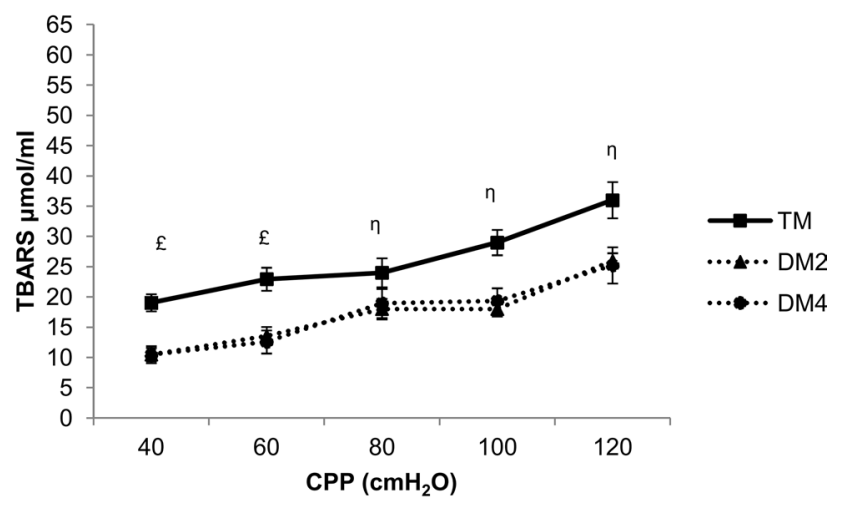

Figure 5. Effects of training/detraining on index of lipid peroxidation determined as TBARS level in coronary venous effluent (TBARS). A. Comparison between control and trained groups. B. Comparison between 2 and 4 weeks detrained groups. C. Comparison between trained, 2 and 4 weeks detrained females. D. Comparison between trained, 2 and 4 weeks detrained males. ${ }^{*} p<0.05$, ${ }^{* *} p<0.01$ TM $v$ s.

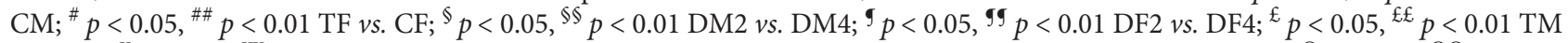

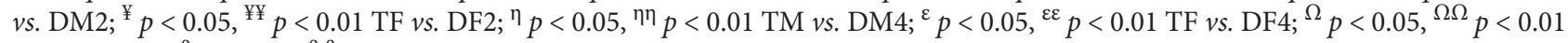
DM2 vs. DF2; ${ }^{\&} p<0.05,{ }^{\& \&} p<0.01$ DM4 vs. DF4. Data are means \pm SD. For abbreviations, see Fig. 2.

0.032). In a 4 weeks detrained group, levels of $\mathrm{NO}_{2}{ }^{-}$was significantly higher in female rats than in male rats $(p=$ 0.026) (Figure 6B).

\section{Levels of hydrogen peroxide $\left(\mathrm{H}_{2} \mathrm{O}_{2}\right)$}

According to the results of one-way ANOVA, there was a statistically significant difference between groups in the level of $\mathrm{H}_{2} \mathrm{O}_{2}(\mathrm{~F}(7,56)=8,125, p=0.00)$. A decrease in the level of $\mathrm{H}_{2} \mathrm{O}_{2}$ in 2 weeks detrained males compared to trained males $(p=0.009)$ and 2 weeks detrained females group compared to trained females group was revealed (0.008). In addition, there was a significant decrease in the level of this parameter in 4 weeks detrained males compared to trained males ( $p=$ $0.007)$. In 4 weeks detrained females levels were increased compared to 2 weeks detrained females $(p=0.006)$. In a group of rats who were subjected to 4 weeks of detraining, levels of $\mathrm{H}_{2} \mathrm{O}_{2}$ were higher in females $(p=0.004)$ (Figure 6C).

\section{Levels of TBARS}

There was a significant difference between groups in the level of TBARS $(F(7,56)=5,125, p=0.01)$. Level of TBARS in plasma increased in trained groups compared to control at females $(p=0.07)$ and males $(p=0.004)$. An increase in the level of this parameter in 4 weeks detrained females compared to trained females $(p=0.029)$ and 2 weeks detrained females $(p=0.034)$ was noticed as well (Figure 6D).

\section{Activity of superoxide dismutase (SOD)}

Activity of SOD differed between groups $(\mathrm{F}(7,56)=7,221$, $p=0.00)$. A significant increase in the activity of this enzyme in trained group in males was observed in comparison to control males $(p=0.023)$. There was a decrease in the activity of SOD in 2 weeks detrained females ( $p=0.021)$ and 4 weeks detrained females $(p=0.009)$ compared to trained females. 
In 4 weeks detrained males activity of SOD was decreased in comparison to 2 weeks detrained males $(p=0.006)$ and trained males $(p=0.008)$. There was a statistically significant increase in SOD activity in male rats compared to female rats in the period of 2 weeks detraining (0.003) (Figure 7A).

\section{Activity of catalase (CAT)}

Statistically significant difference between groups in the activity of catalase $(\mathrm{F}(7,56)=10,221, p=0.00)$ was found. There was an increase in the activity of catalase (CAT) in trained group compared to the control group in females $(p=0.008)$, while in males the difference was not significant. In 2 weeks detrained females the activity was decreased compared to trained females $(p=0.009)$. A decrease in the activity of CAT was observed in 4 weeks detrained females compared to trained females $(p=0.032)$, and that value was increased compared to 2 weeks detrained females $(p=0.029)$. An increased activity was noticed in 4 weeks detrained males compared to trained males $(p=0.009)$ and 2 weeks detrained males $(p=0.016)$. The only difference in values between males and females was found in trained groups, where females had higher values of CAT activity $(p=0.006)$ (Figure 7B).

\section{Levels of reduced glutathione (GSH)}

There was a statistically significant difference between groups in the level of $\operatorname{GSH}(\mathrm{F}(7,56)=4,298, p=0.02)$. Level of reduced glutathione ( $\mathrm{GSH}$ ) was significantly increased in trained groups compared to control groups in females $(p=0.002)$ and males $(p=0.003)$. In 2 weeks detrained males values were increased compared to trained males $(p=$ 0.027). In 4 weeks detrained males group level of GSH was increased compared to trained males $(p=0.022)$. In addition, level of GSH was lower in 4 weeks detrained females than in 2 weeks detrained females $(p=0.021)$. Gender difference in 4 detrained females in comparison to the 4 weeks detrained males group was noticed, where values in female rats were lower than in male rats (0.018) (Figure 7C).
A

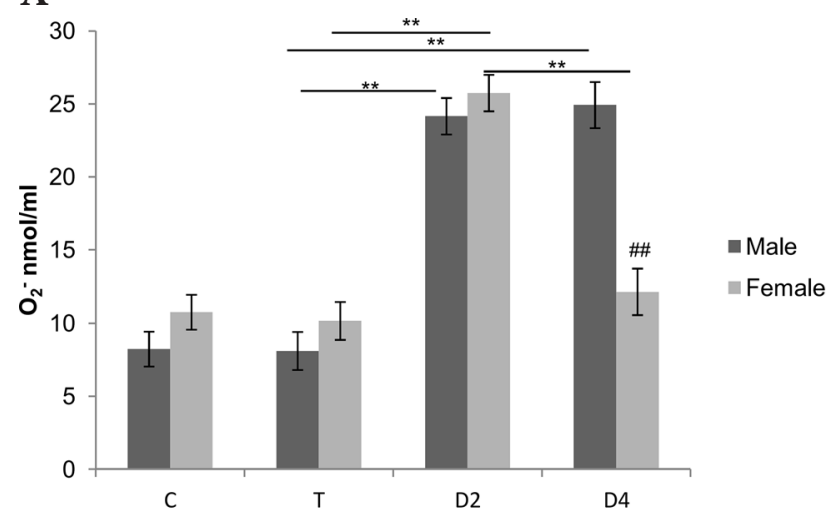

C

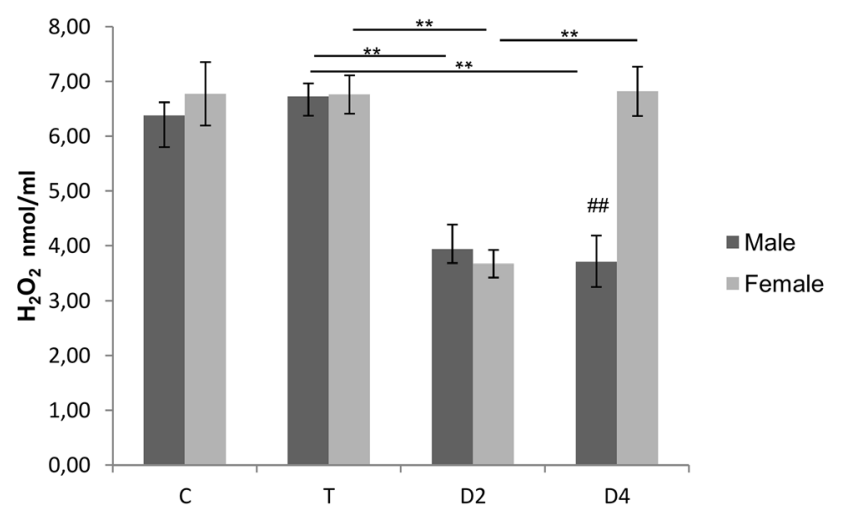

B

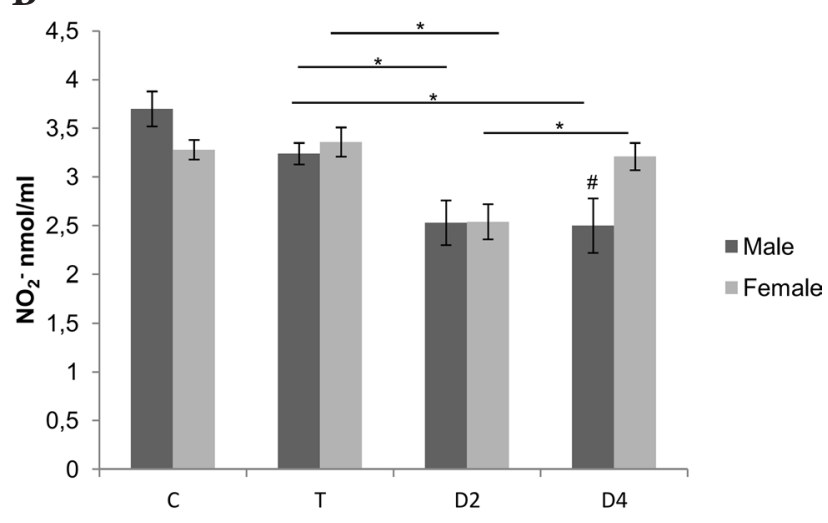

D

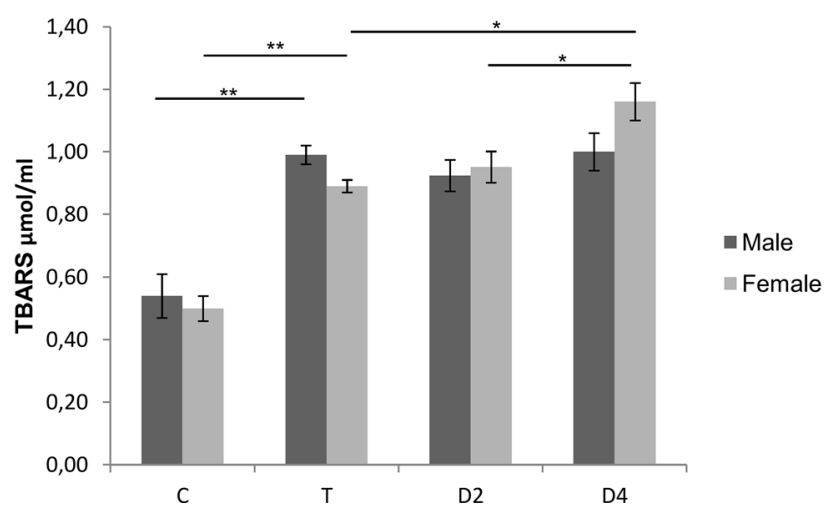

Figure 6. Effects of training/detraining on level of pro-oxidants determined in plasma: $\mathrm{O}_{2}(\mathbf{A}), \mathrm{NO}_{2}{ }^{-}(\mathbf{B}), \mathrm{H}_{2} \mathrm{O}_{2}(\mathbf{C}), \mathrm{TBARS}(\mathbf{D}){ }^{*} p<$ $0.05,{ }^{* *} p<0.01 \mathrm{C} v s . \mathrm{T} v s . \mathrm{D} 2$ vs. D4; ${ }^{\#} p<0.05,{ }^{\# \#} p<0.01$ males $v$ s. females. Data are means $\pm \mathrm{SD}$. C, control group; T, trained group; D2, 2 weeks detrained group; D4, 4 weeks detrained group. 
A

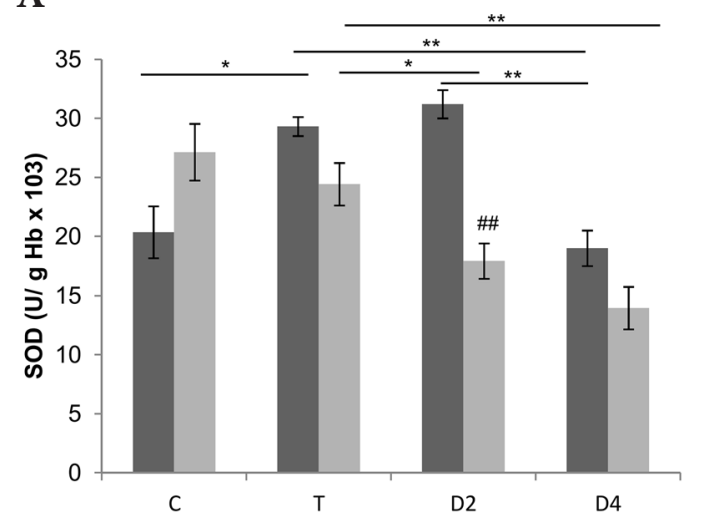

C

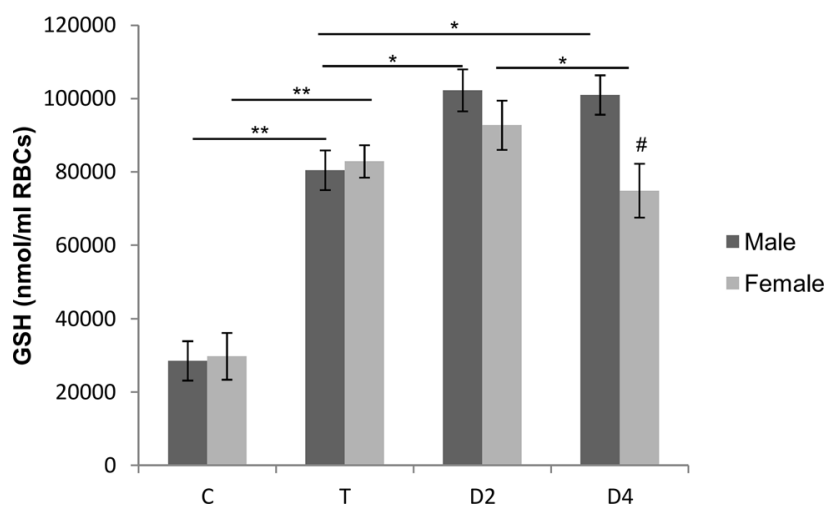

\section{Discussion}

Potential source of oxidative stress during anaerobic training is an increased aerobic metabolism (Stankovic and Radovanovic 2012). ROS and RNS production during exercise follows the principal of hormesis and may represent an adaptive response of cells to stressors, such as physical activity. The responses of biological systems may be described with a bell-shaped curve whose two endpoints are inactivity and overtraining (Stojanovic Tosic et al. 2015; Radak et al. 2017).

Numerous investigations aimed to examine the influence of aerobic exercise on oxidative stress markers were mostly focused on treadmill or cycle ergometer (Powers et al. 2016). We've chosen to examine the effects of swimming training due to the fact that swimming is considered as a natural ability of rats and it has also been proposed as a convenient model for studying the physiological changes and stress response to training (Balci and Pepe 2012; Araujo et al. 2015).

Results of our study clearly show that 8 weeks of swimming training led to the decrease of almost all pro-oxidants measured in the heart both in male and female rats. Analysis of aforementioned parameters in the coronary venous efflu-
B

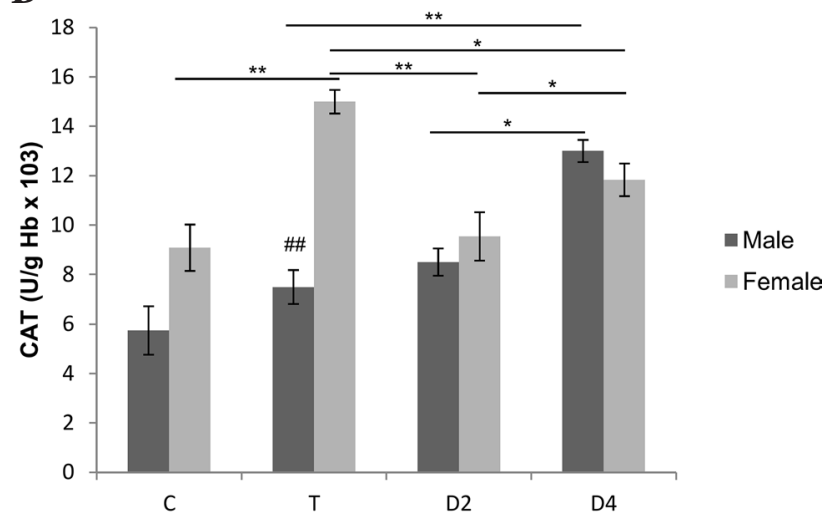

Figure 7. Effects of training/detraining on parameters of antioxidant defense system determined in erythrocytes samples: $\mathrm{SOD}(\mathbf{A})$, CAT (B), GSH (C). ${ }^{*} p<0.05,{ }^{* *} p<0.01 \mathrm{C}$ vs. T vs. D2 vs. D4; ${ }^{\#}$ $p<0.05,{ }^{\# \#} p<0.01$ males $v s$. females. Data are means \pm SD. For abbreviations, see Fig. 6 .

ent during coronary autoregulation refers to the oxidative stress in the endocardium of the left ventricle and endothelium of the coronary circulation as well. In order to complete the picture about the role of oxidative stress in physiology of effort, we investigated the systemic oxidative stress response to training and detraining. Generally viewed, there were no changes in the release of the measured pro-oxidants in plasma, thus suggesting that applied intensity and duration of swimming training may affect only local production of ROS (in the heart), while systemic response was not changed. In addition, having in mind that release of pro-oxidants was even decreased in the heart, it seems that swimming training of this type doesn't promote oxidative damage, nor act protectively within the heart.

Regarding the components of antioxidant defense system, SOD, CAT and GSH, training led to the significant increase of GSH values at both sexes, CAT in females and SOD in males. It can be assumed that effects of training on these antioxidant parameters depend on their chemical characteristics. Also, results for these enzymes can not be interpreted independently of $\mathrm{O}_{2}{ }^{-} / \mathrm{H}_{2} \mathrm{O}_{2}$ dynamic. In female, unchanged activity of SOD in training induced less scavenging of $\mathrm{O}_{2}^{-}$, leading to higher $\mathrm{H}_{2} \mathrm{O}_{2}$ values (compared to 2 weeks detrained group), which can induce enhanced CAT 
activity. Increased activity of antioxidants is in correlation with unaltered levels of pro-oxidants in the plasma and may explain these results.

Our results are in agreement with the study conducted by Balci et al. who found decreased malondialdehyde (MDA) levels in the heart of female rats at rest, however they didn't observe any change in MDA and NO levels in male rats in the heart (Balci and Pepe 2012). Neither did we reveal the difference in level of $\mathrm{NO}_{2}{ }^{-}$in the heart when compared trained and untrained rats both sexes at rest. The potential explanation for this may be the interaction of NO with reactive oxygen species (ROS), particularly $\mathrm{O}_{2}{ }^{-}$. Significantly lower levels of $\mathrm{O}_{2}{ }^{-}$in the present study may be a consequence of this interaction resulting in generation of peroxynitrite $\left(\mathrm{ONOO}^{-}\right)$.

A group of researchers whose methodology differed from ours in case of duration of swimming training noticed that this type of activity reduced lipid peroxidation in the heart (Venditti and Di Meo 1997). It should be taken into consideration that pro-oxidants detected in blood plasma and erythrocytes reflect the redox state of all components which are included in the motor act during physical exercise. In that sense it's logical to expect the different values of parameters of oxidative stress response measured in heart and in plasma (Elikov 2016). Furthermore, Hu et al. (2000) observed no change in the lipid peroxidation level in heart, which may be explained by a shorter period of swimming training ( 7 days, 45 minutes per day) insufficient to establish positive adaptations to exercise.

When discussing antioxidant defense system, our results are not in accordance with the results of Balci and Pepe (2012) who revealed that 8 weeks of swimming training caused a decrease in SOD activity and didn't affect total GSH levels in rat heart. Furthermore, Lima and co-workers proved increased reduced glutathione (GSH) content and reduced/oxidized (GSH/GSSG) ratio, higher superoxide dismutase activity in liver mitochondria after 6-week swimming training protocol (Lima et al. 2013). Others showed an increase in serum superoxide dismutase activity induced by swimming as well (Botezelli et al. 2011). We expected that gender differences in response to training exist, since it's been reported that female rats often show lower oxidative damage than males (Stankovic and Radovanovic 2012). However, values of all measured pro-oxidants were similar in female and male rats in training.

It's been known that the exercise-induced adaptive process is reversible in case of cardiovascular function and mitochondrial enzyme activity (Mujika and Padilla 2000). After 2 weeks of detraining, the release of $\mathrm{O}_{2}$ and $\mathrm{H}_{2} \mathrm{O}_{2}$ in the heart was increased compared to the values in training. Regarding the systemic response, we noticed the same trend in $\mathrm{O}_{2}$ production, while levels of $\mathrm{NO}_{2}{ }^{-}$and $\mathrm{H}_{2} \mathrm{O}_{2}$ were decreased in comparison to the levels in training. The explanation for decreased plasma level in $\mathrm{H}_{2} \mathrm{O}_{2}$ detraining period may be an increased catalase activity during training, which catalyzed the decomposition of hydrogen peroxide to water and oxygen. Furthermore, SOD and CAT activity were lower after 2 weeks of training cessation in females and level of GSH was higher in males in comparison with the values in training. The difference between gender that we noticed was an increased activity of SOD in males and higher TBARS production in heart of females.

We detected an increase in cardiac release of $\mathrm{O}_{2}$ at both sexes and $\mathrm{H}_{2} \mathrm{O}_{2}$ at males after four weeks of training cessation compared to the values in training. Interestingly, after 4 weeks of detraining levels of the most of measured pro-oxidants in females were similar to those in training. Regarding the parameters of antioxidant defense system, 4 weeks detraining led to the decrease in SOD activity at both sexes and CAT in females compared with training. On the contrary, GSH and CAT values in males remained increased in detraining. There is a data that increased total antioxidant capacity was associated with an increased circulating CD $34^{+}$/ VEGFR2 ${ }^{+}$cells in detraining (Witkowski et al. 2010).

Radak et al. examined the effects of 8 weeks of swimming and 8 weeks of detraining on the level of free radical species in the cerebellum. They proved that positive effects of training were maintained during detraining (Radak et al 2006). Others showed that 16 week of walking/jogging at $50-80 \%$ of $\mathrm{HR}(\max )$ decreased MDA levels and increased total antioxidant capacity (TAC) and glutathione peroxidase activity (GPX) (Fatouros et al. 2004). However after 4 months of training cessation those effects were eliminated. It has been previously reported that effects of treadmill training on paraventricular nucleus in hypertensive rats reversed after 2 weeks of training cessation (Agarwal et al. 2012).

Although estrogen $17 \beta$-estradiol and different levels of ferritin may be responsible for the higher antioxidant protection noticed in females compared to males, we revealed lower antioxidant protection in females during detraining (Català-Niell et al. 2008; Stankovic and Radovanovic 2012). Based on our results we may hypothesize that probably there are other mechanisms independent of the change in estrogen and iron metabolism, thus contributing to sex differences in oxidative-stress response to exercise cessation. Beside mentioned mechanisms involved in effects of training/detraining on diversity between male and female antioxidative status, a very recent study on rats have shown gender difference in mitochondrial function which can be affected by exercise or cessation of it (Farhat et al. 2017). It can be assumed that diminshed mitochondrial activity can lead to depressed production of mitochondrial SOD and thus impair functioning of cellular antioxidant pathways (Macak-Safranko et al. 2011). Lower antioxidant values in our study support higher pro-oxidant levels after 4 weeks of detraining noticed in females. 
We confirmed the fact that sexual dimorphism in oxidative capacity exists. These results suggest different dynamic of production of specific pro-oxidants among sexes during period of training cessation. One of limitations of our investigation was the absence of technique through which cellular mechanisms of obtained effects could be proved. Therefore further studies are necessary for better understanding the possible mechanisms underlying the gender differences in response to training and detraining.

Our results illustrated that moderate-intensity physical exercise of sufficient duration leads to the beneficial adaptations, manifested as improvement of antioxidant defense system. In addition, these results suggest that 2 and 4 weeks of training cessation may lead to a partial lost in exercise-induced adaptation. Positive antioxidative effects of training remained longer in males. Findings of the present study may help in elucidation of training and detraining effects on modulation of redox homeostasis, especially from aspect of gender differences.

Acknowledgement. This work was supported by Junior project 09/11, by Faculty of Medical Sciences, Kragujevac, Serbia.

\section{References}

Agarwal D, Dange RB, Vila J, Otamendi AJ, Francis J (2012): Detraining differentially preserved beneficial effects of exercise on hypertension: effects on blood pressure, cardiac function, brain inflammatory cytokines and oxidative stress. PLoS One 7, e52569 https://doi.org/10.1371/journal.pone.0052569

Ammeren J, Powers S, Lawler J, Criswell D, Martin D, Lowenthal D, Pollock M (1992): Exercise training-induced alterations in skeletal muscle oxidative and antioxidant enzyme activity in senescent rats. Int. J. Sports Med. 13, 412-416 https://doi.org/10.1055/s-2007-1021290

Araujo LC, de Souza IL, Vasconcelos LH, Brito AF, Queiroga FR, Silva AS, da Silva PM, Cavalcante FA, da Silva BA (2015): Chronic aerobic swimming exercise promotes functional and morphological changes in rat ileum. Biosci. Rep. 35, e00259 https://doi.org/10.1042/BSR20150001

Auclair C, Voisin E (1985): Nitroblue tetrazolium reduction. In: Handbook of Methods for Oxygen Radical Research. (Ed. RA Greenvvald), pp. 123-132, Boka Raton, CRC Press, Greenvvald Ine

Balci SS, Pepe H (2012): Effects of gender, endurance training and acute exhaustive exercise on oxidative stress in the heart and skeletal muscle of the rat. Chin. J. Physiol. 55, 236-244

Beutler E (1975): Reduced glutathione (GSH). In: Red Cell Metabolism, a Manual of Biochemical Methods. (Ed. E. Beutler), pp. 112-114, Grune and Stratton, New York

Beutler E (1982): Catalase. In: Red Cell Metabolism, a Manual of Biochemical Methods. (Ed. E. Beutler), pp. 105-106, Grune and Stratton, New York

Birben E, Sahiner UM, Sackesen C, Erzurum S, Kalayci O (2012): Oxidative stress and antioxidant defense. World Allergy Organ. J. 5, 9-19
https://doi.org/10.1097/WOX.0b013e3182439613

Botezelli JD, Cambri LT, Ghezzi AC, Dalia RA, Scariot MPP, Ribeiro C, Voltarelli FA, Mello MA (2011): Different exercise protocols improve metabolic syndrome markers, tissue triglycerides content and antioxidant status in rats. Diabetol. Metab. Syndr. 3, 35 https://doi.org/10.1186/1758-5996-3-35

Català-Niell A, Estrany ME, Proenza AM, Gianotti M, Lladó I (2008): Skeletal muscle and liver oxidative metabolism in response to a voluntary isocaloric intake of a high fat diet in male and female rats. Cell Physiol. Biochem. 22, 327-336 https://doi.org/10.1159/000149811

Davies KJ, Quintanilha AT, Brooks GA, Packer L (1982). Free radicals and tissue damage produced by exercise. Biochem. Biophys. Res. Commun. 107, 1198-1205 https://doi.org/10.1016/S0006-291X(82)80124-1

Dillard CJ, Litov RE, Savin WM, Dumelin EE, Tappel AL (1978): Effects of exercise, vitamin E, and ozone on pulmonary function and lipid peroxidation. J. Appl. Physiol. Respir. Environ. Exerc. Physiol. 45, 927-932 https://doi.org/10.1152/jappl.1978.45.6.927

Elikov AV (2016): Oxidative balance in rats during adaptation to swimming load. Bull. Exp. Biol. Med. 162, 180-183 https://doi.org/10.1007/s10517-016-3570-4

Farhat F, Amérand A, Simon B, Guegueniat N, Moisan C (2017): Gender-dependent differences of mitochondrial function and oxidative stress in rat skeletal muscle at rest and after exercise training. Redox Rep. 1. 1-7 https://doi.org/10.1080/13510002.2017.1296637

Fatouros IG, Jamurtas AZ, Villiotou V, Pouliopoulou S, Fotinakis P, Taxildaris K, Deliconstantinos G (2004): Oxidative stress responses in older men during endurance training and detraining. Med. Sci. Sports Exerc. 36, 2065-2072 https://doi.org/10.1249/01.MSS.0000147632.17450.FF

Gomez-Cabrera MC, Domenech E, Romagnoli M, Arduini A, Borras C, Pallardo FV, Sastre J, Vina J (2008): Oral administration of vitamin $\mathrm{C}$ decreases muscle mitochondrial biogenesis and hampers training-induced adaptations in endurance performance. Am. J. Clin. Nutr. 87, 142-149 https://doi.org/10.1093/ajcn/87.1.142

Green LC, Wagner DA, Glogowski J, Skipper PL, Wishnok JS, Tannenbaum SR (1982): Analysis of nitrate, nitrite and [15N] nitrate in biological fluids. Anal. Biochem. 126, 131-138 https://doi.org/10.1016/0003-2697(82)90118-X

Hu Y, Gursoy E, Cardounel A, Kalimi M (2000): Biological effects of single and repeated swimming stress in male rats. Endocrine 13, 123-129 https://doi.org/10.1385/ENDO:13:1:123

Lima FD, Stamm DN, Della-Pace ID, Dobrachinski F, de Carvalho NR, Royes LF, Soares FA, Rocha JB, González-Gallego J, Bresciani G (2013): Swimming training induces liver mitochondrial adaptations to oxidative stress in rats submitted to repeated exhaustive swimming bouts. PLoS One 8, e55668 https://doi.org/10.1371/journal.pone.0055668

Liu J, Yeo HC, Overvik-Douki E, Hagen T, Doniger SJ, Chyu DW, Brooks GA, Ames BN (2000): Chronically and acutely exercised rats: biomarkers of oxidative stress and endogenous antioxidants. J. Appl. Physiol. 89, 21-28 https://doi.org/10.1152/jappl.2000.89.1.21 
Macak-Safranko Z, Sobocanec S, Saric A, Balog T, Sverko V, Kusic B, Marotti T (2011): Cytochrome P450 gender-related differences in response to hyperoxia in young CBA mice. Exp. Toxicol. Pathol. 63, 345-350 https://doi.org/10.1016/j.etp.2010.02.009

Macera CA, Hootman JM, Sniezek JE (2003): Major public health benefits of physical activity. Arthritis Rheum. 49, 122-128 https://doi.org/10.1002/art.10907

McCord JM, Fridovich I (1969): The utility of superoxide dismutase in studying free radical reactions. Radicals generated by the interaction of sulfite, dimethyl sulfoxide, and oxygen. J. Biol. Chem. 244, 6056-6063

Misra HP, Fridovich I (1972): The role of superoxide-anion in the autooxidation of epinephrine and a simple assay for superoxide dismutase. J. Biol. Chem. 247, 3170-3175

Mujika I, Padilla S (2000): Detraining: loss of training-induced physiological and performance adaptations. Part I: short term insufficient training stimulus. Sports Med. 30, 79-87 https://doi.org/10.2165/00007256-200030020-00002

Ohkawa H, Ohishi N, Yagi K (1979): Assay for lipid peroxides in animal tissues by thiobarbituric acid reaction. Anal. Biochem. 95, 351-358 https://doi.org/10.1016/0003-2697(79)90738-3

Pham-Huy LA, He H, Pham-Huy C (2008): Free radicals, antioxidants in disease and health. Int. J. Biomed. Sci. 4, 89-96

Pick E, Keisari Y (1980): A simple colorimetric method for the measurement of hydrogen peroxide produced by cells in culture. J. Immunol. Methods 38, 161-170 https://doi.org/10.1016/0022-1759(80)90340-3

Powers SK, Jackson MJ (2008): Exercise-induced oxidative stress: cellular mechanisms and impact on muscle force production. Physiol. Rev. 88, 1243-1276 https://doi.org/10.1152/physrev.00031.2007

Powers SK, Radak Z, Ji LL (2016): Exercise-induced oxidative stress: past, present and future. J. Physiol. 594, 5081-5092 https://doi.org/10.1113/JP270646

Radak Z, Ishihara K, Tekus E, Varga C, Posa A, Balogh L, Boldogh I, Koltai E (2017): Exercise, oxidants, and antioxidants change the shape of the bell-shaped hormesis curve. Redox Biol. 12, 285-290 https://doi.org/10.1016/j.redox.2017.02.015

Radak Z, Toldy A, Szabo Z, Siamilis S, Nyakas C, Silye G, Jakus J, Goto S (2006): The effects of training and detraining on memory, neurotrophins and oxidative stress markers in rat brain. Neurochem. Int. 49, 387-392 https://doi.org/10.1016/j.neuint.2006.02.004

Rahal A, Kumar A, Singh V, Yadav B, Tiwari R, Chakraborty S, Dhama K (2014): Oxidative stress, prooxidants, and antioxidants: the interplay. Biomed. Res. Int. 2014, 761264 https://doi.org/10.1155/2014/761264

Ruzicic RD, Jakovljevic V, Djordjevic D (2016): Oxidative stress in training, Overtraining and detraining: from experimental to applied research. Ser. J. Exp. Clin. Res. 17, 343-348 https://doi.org/10.1515/sjecr-2016-0002

Stanković M, Radovanović D (2012): Oxidative stress and physical activity. Sport Logia 8, 1-11 https://doi.org/10.5550/sgia.120801.en.001S

Stojanovic Tosic JT, Jakovljevic VLj, Zivkovic VV, Srejovic IM, Valdevit ZJ, Radovanovic DS, Djuric DM, Ahmetovic ZK, Peric DB, Cankovic MB, Jovanovic MS (2015): Biphasic response of cardiodynamic adaptations to swimming exercise in rats. Gen. Physiol. Biophys. 34, 301-310 https://doi.org/10.4149/gpb_2015001

Venditti P, Di Meo S (1997): Effect of training on antioxidant capacity, tissue damage, and endurance of adult male rats. Int. J. Sports Med. 18, 497-502 https://doi.org/10.1055/s-2007-972671

Vina J, Sanchis-Gomar F, Martinez-Bello V, Gomez-Cabrera MC (2012): Exercise acts as a drug; the pharmacological benefits of exercise. Br. J. Pharmacol. 167, 1-12 https://doi.org/10.1111/j.1476-5381.2012.01970.x

Witkowski S, Lockard MM, Jenkins NT, Obisesan TO, Spangenburg EE, Hagberg JM (2010): Relationship between circulating progenitor cells, vascular function and oxidative stress with long-term training and short-term detraining in older men. Clin. Sci. (Lond) 118, 303-311 https://doi.org/10.1042/CS20090253

Received: July 28, 2017

Final version accepted: November 2, 2017 